\title{
PENGARUH KESELAMATAN DAN KESEHATAN KERJA (K3) DAN TURN OVER INTENTION TERHADAP PRODUKTIVITAS KERJA PADA PT. PERSADA MANDIRI YANG BERGERAK DI BIRO PENCATATAN KWH PT. PLN (Persero) PADANG
}

\author{
Syahril \\ Universitas Dharma Andalas Padang \\ syahrilsenyo@gmail.com
}

\begin{abstract}
This research is entitled "The effect of occupational safety and health (K3) and Turn Over Intention on work productivity at PT. Persada Mandiri which is engaged in the KWH recording bureau of PT. PLN (Persero) Padang”, which aims to find out how much the independent variable can have a significant effect on work productivity at PT. This Independent Persada. This study uses three variables, namely two independent variables Occupational Safety and Health (K3) as (X1) and Turn Over Intention as (X2) and one dependent variable, namely Work Productivity as (Y). Occupational Safety and Health (K3) is a variable that can affect work productivity, because if employees are sickly they cannot walk from house to house as well as Turn Over intention, if employees often come in and out this will also disrupt the company's activities. If the company's activities are disrupted, of course, work productivity will not be achieved. The analytical method used in this research is multiple linear regression analysis method with sampling technique using total sampling technique because the population is small, namely 47 people. The results of this study indicate that the variables of Occupational Safety and Health (K3) or (XI) have a significant effect on Work Productivity and Turn Over Intention also has a significant effect on Work Productivity. Furthermore, according to the simultaneous test the two independent variables have a significant effect on work productivity.
\end{abstract}

Keywords: Occupational Safety and Health, Labor Intention and Work Productivity

Abstrak : Penelitian ini berjudul "Pengaruh keselamatan dan kesehatan kerja (K3) dan Turn Over Intention terhadap Produktivitas kerja pada PT.Persada Mandiri yang bergerak di Biro pencatatan KWH PT. PLN (persero) Padang", yang nertujuan untuk mengetahui seberapa besar variabel bebas dapat berpengaruh signifikan terhadap produktivitas kerja pada PT. Persada Mandiri ini. Penelitian ini menggunakan tiga variabel yaitu dua variabel bebas Keselamatan dan Kesehatan Kerja (K3) sebagai (X1) dan Turn Over Intention sebagai (X2) dan satu variabel terikat yaitu Produktivitas Kerja sebagai (Y). Keselamatan dan Kesehatan kerja (K3) ini variabel yang dapat mempengaruhi Produktivitas kerja, sebab kalau karyawan sakit-sakitan tidak dapat berjalan dari rumah ke rumah demikian pula halnya dengan Turn Over intention apabila sering terjadi karyawan keluar masuk ini juga akan mengganggu aktivitas perusahaan. Apabila aktivitas perusahaan terganggu tentu Produktiviyas kerja tidak akan tercapai. Metode analisa yang digunakan dalam penelitian ini adalah metode analisis regresi linear berganda dengan teknik pengambilan sampel menggunakan teknik total sampling karena populasi kecil yaitu 47 orang. Hasil penelitian ini menunjukkan dimana variabel Keselamatan dan Kesehatan Kerja (K3) atau (X1) berpengaruh signifikan terhadap Produktivitas Kerja dan begitu juga dengan Turn Over Intention juga berpengaruh signifikan terhadap Produktivitas kerja. Selanjutnya menurut uji simultan kedua variabel bebas berpengaruh signifikan terhadap produktivitas kerja. 
Kata Kunci : Keselamatan dan Kesehatan Kerja, Labour Intention dan Produktivitas Kerja.

\section{A. PENDAHULUAN}

Produktivitas suatu perusahaan sangat ditentukan oleh aktivitas sumber daya manusianya untuk keberhasilan perusahaan dalam melaksanakan kegiatan operasional sehari-hari. Dalam artian apakah produktifitas yang diprogramkan dapat dilaksanakan dengan baik atau tidak baik. Pelaksanaan aktivitas tersebut tidak lepas dari peranan karyawan sebagai personil pelaksana. Dalam hal ini aktivitas karyawan akan bergantung pada kondisi keselamatan dan kesehatan kerja karyawan dan rendahnya turnover Intentention, karena kedua hal ini sangat berdampak kepada peningkatan produktivitas kerja karyawan tersebut.

Keselamatan dan kesehatan kerja adalah bidang yang terkait dengan kesehatan, keselamatan dan kesejahteraan manusia disebuah institusi maupun lokasi proyek hal ini sesuai dengan pendapat Widodo (2015). Selain melaksanakan keselamatan kerja dapat tercapai dengan baik yaitu dengan cara adanya partisipasi dari kedua bela pihak. Keselamatan kerja dapat membantu peningkatan produktivitas kerja karyawan, dimana dapat kegairahan, semangat dan kecepatan kerja yang lebih efektif.

Selanjutnya selain dari keselamatan dan kesehatan kerja ada juga faktor yang lebih penting lainnya yaitu Turn Over intention untuk meningkatkan produktivitas kerja walaupun pergantian karyawan itu mempunyai dampak positif dan dampak negative tetapi tetap saja pergantian karyawan ini kurang baik terutama dari segi biaya maupun hilangnya waktu dan memanfaatkan peluang hal ini senada dengan pendapat Mobley (2011). Sebab pada PT Perdsada Mandiri yang bergerak dibidang pencatatan KWH sebagai perpanjangan tangan PT. PLN ini sering terjadi turnover Intention. Untuk Produktivitas kerja,seperti penagihan piutang pelanggan PT. PLN (Persero) cabang padang rayon belanti, indarung, tabing, dan kuranji, dapat diukur dengan membandingkan jumlah pelanggan yang tertagih dengan total pelanggan yang pembayaran listriknya menunggak. Untuk pekerjaan penagiahan piutang ini juga dipercayakan kepada para karyawan yang mencatat KWH dari rumah ke rumah.

\section{B. TINJAUAN PUSTAKA}

\section{Keselamatan dan Kesehatan Kerja (K3)}

Upaya perlindungan tenaga kerja maupun pembinaan keselamatan dan kesehatan kerja mendapat perhatian penting di Indonesia.

Keselamatan dan kesehatan kerja akan membawa iklim keamanan dan ketenangan kerja, sehingga sangat membantu bagi hubungan karyawan dan pemimpin yang merupakan landasan kuat untuk terciptanya kelancaran produksi. Menurut Hadiwiroyo (2004) Keselamatan kerja adalah menciptakan suatu usaha kesatuan kerja dengan melibatkan unsur manajemen, tenaga kerja, kondisi, dan lingkungan kerja yang terintegrasi dalam rangka mencegah dan mengurangi kecelakaan dan penyakit akibat bekerja, serta terciptanya tempat kerja yang aman, efisien dan produktif.

Menurut Widodo (2015), Kesehatan dan Keselamatan Kerja (K3) adalah bidang yang terkait dengan kesehatan, keselamatan, dan kesejahteraan manusia yang bekerja di sebuah institusi maupun lokasi proyek. Menurut Rivai dan Sagala (2013), Keselamatan dan Kesehatan Kerja menunjuk kepada kondisi-kondisi fisiologis-fisikal dan psikologis tenaga kerja yang diakibatkan oleh lingkungan kerja yang disediakan oleh perusahaan. 
Dari beberapa defenisi diatas dapat disimpulkan bahwa yang dimaksud dengan keselamatan dan kesehatan kerja adalah kesejahteraan manusia yang bekerja pada suatu perusahaan dengan kondisi psikologis dan lingkungan kerja yang nyaman.

\section{Pengertian Turnover Intention}

Turnover Intention, keinginan berpindah kerja dari suatu perusahaan atau organisasi yang biasanya disebabkan oleh ketidak cocokan dan ketidak puasan seseorang terhadap pekerjaan atau organisasi maka dari itu ada niat untuk berpindah atau mengeluarkan diri dari pekerjaannya. Tetapi Turnover Intention ini belum sampai ke tahap seseorang mengundurkan diri dari pekerjaannya atau organisasi, jadi organisasi masih bisa untuk mempertahannkan anggotanya agar tetap berada di dalam organisasi tersebut.

Menurut Robbins dan Judge (2015) Turnover Intention adalah kecenderungan atau tingkat dimana seorang karyawan untuk meninggalkan perusahaan baik secara sukarela maupun tidak sukarela yang disebabkan kurang menariknya pekerjaan saat ini dan tersedianya alternatif pekerjaan lain.

Meninggalkan pekerjaan dengan sukarelawan adalah seseorang yang berniat meninggalkan organisasi atas keinginan sendiri karena beberapa sebab. Sedangkan keputusan meninggalakan pekerjaan dengan secara tidak sukarelawan adalah menghentikan hubungan kerja seseorang di dalam sebuah perusahaan(pemecataan)

Menururt Yeoh dkk (2010) Turnover intention adalah niat karyawaan untuk berpindah tempat dan mencari alternatif pekerjaan yang dianggapnya lebih menarik daripada pekerjaan sebelumnya, dan begitupula dengan Abdillah (2012) dalam Septiari, Ardana (2016) Turnover intention merupakan suatu keadaan dimana pekerja memiliki niat atau kecenderungan yang dilakukan secara sadar untuk mencari suatu pekerjaan lain sebagai alternatif di organisasi yang berbeda dan turnover adalah penggerak keluarnya tenaga kerja dari tempatnya bekerja.

Dari beberapa defenisi diatas dapat disimpulkan yang dimaksud dengan turnover intention adalah niat pekerja atau karyawan untuk mencari pekerjaan lain yang lebih baik dan dapat memuaskan kebutuhan secara psikologis. Penyebab munculnya Turnover Intention ada 2 hal yakni keinginan karyawan itu sendiri untuk mengundurkan diri dari pekerjaannya dan pemberhentian karyawan oleh atasan.

Sedangkan untuk pemberhentiaan pekerjaan (pemecataan) biasanya karyawan telah melakukan kesalahan dan biasanya kinerja karyawan tersebut sangat buruk dan tidak bisa untuk di atasi kembali.

\section{Faktor akibat/dampak (konsukensi)}

Semakin tinggi adanya turnover intention berarti semakin sering pergantiaan karyawan. Menurut Novita (2011) dampak negatif adanya turnover intention yang memberikan dampak kepada peusahaan antara lain:

Biaya penarikan karyawan. Waktu yang efisien menjadi terbuang untuk wawancara dalam proses seleksi karyawaan

1. Biaya latihan untuk karyawaan baru yang menyangkut waktu pengawas, departemen personalia dan karyawan yang dilatih.

2. Tingkat kecelakaan para karyawan baru, biasanya cenderung tinggi sebabkaryawaan baru belum begitu banyak mengetahui prosedur perusahaan.

3. Banyak pemborosan karena adanya karyawan baru contohnya rekruitmen,pelatihan

4. Perlu melakukan kerja lembur, kalau tidak akan mengalami penundaan penyerahan. 
Menurut Mobley ( 2011 ) ada tiga indikator turnover intention karyawan, yaitu :

1. Pikiran untuk berhenti bekerja (thoughts of quitting). Adanya pikiran berhenti bekerja karena karyawan merasa tidak puas dengan keadaan pekerjaan yang sekarang, sehingga memicu untuk berkurangnya kehadiran dalam bekerja.

2. Hasrat untuk meninggalkan karir (intention to quit). Mencerminkan individu untuk mencari pekerjaan pada organisasi lain. Jika karyawan sudah mulai sering berfikir untuk keluar dari pekerjaannya, karyawan tersebut akan mencoba mencari pekerjaan di luar perusahaannya yang dirasa lebih baik.

3. Hasrat untuk mencari pekerjaan lain (intention to search for another job). Adanya kecenderungan karyawan keluar dari perusahaan karena mendapatkan tawaran pekerjaan di luar yang menurutnya lebih menarik dibandingkan dengan tempat bekerjanya sekarang.

\section{Pengertian Produktivitas Tenaga Kerja}

Produktivitas merupakan kemampuan seseorang dalam melaksanakan pekerjaannya untuk memperoleh hasil yang memuskan baik secara kualitas maupun kuantitas.Hal ini tentu berkaitan dengan perbandingan hasil (input) dengan keluaran ( output).

Menurut Sutrisno (2011) produktivitas adalah ukuran efisiensi productive suatu perbandingan hasil keluaran dan masukan. Masukan sering dibatasi dengan tenaga kerja sedangkan keluaran diukur dalam satuan fisik, bentuk dan nilai. Selanjutnya menurut Hasibuan (2010) mengungkapkan bahwa secara lebih sederhana produktivitas adalah perbandingan secara ilmu hitung antara jumlah yang dihasilkan dari jumlah setiap sumber yang dipergunakan selama produksi berlangsung.

Berdasarkan pengertian diatas, jelas terlihat konsep peningkatan produktivitas dapat dimasukan secara analogis dengan proses produksi, dimana pengertian produktivitas secara umum bergantung pada unsur utama yaitu:

a. Efisiensi, dengan kaitannya menggunakan sumber daya atau masukan

b. Efektifitas, yang dalam kaitannya dengan penggunaan sumber daya

Kesimpulan dari beberapa teori diatas bahwa produktivitas adalah: suatu ukuran mengenai apa yang diperoleh dari apa yang dibutuhkan. Karyawan memegang peranan utama dalam proses peningkatan produktivitas, karena alat produksi dan teknologi pada hakikatnya merupakan hasil karya manusia. Produktivitas karyawan mengandung pengertian pernbandingan hasil yang dicapai karyawan dengan jangka waktu tertentu.

Menurut Ravianto (1997) faktor-faktor yang mempengaruhi produktivitas tenaga kerja dapat dibagi menjadi tiga kelompok, yaitu:

1. Kualitas dan kemampuan karyawan

Kualitas dan kemampuan karyawan sangat ditentukan oleh tingkat pendidikan, latihan,motivasi kerja, mental dan kemampuan fisik karyawan.

2. Sarana pendukung

Untuk meningkatkan produktivitas kerja karyawan suatu perusahaan, sarana pendukung yang harus diperhatikanadalah menyangkut:

- Lingkungan kerja, termasuk teknologi dan sarana atau peralatan produksi, keselamatan dan kesehatan kerja serta dalam lingkungan kerja.

3. Supra sarana, antara lain:

- Hubungan industrial

- Kemampuan dan peranan manajemen

- Kesempatan dan peranan berprestasi 
Kebijaksanaan pemerintah

Menurut Gaspersz (2000) strategi paningkatan produktivitas dapat dilakukan melalui lima cara yg harus disesuaikan dengan situasi dan kondisi perushaan.

1. Menerapkan program reduksi biaya

Merupakan suatu program yang diterapkan industri, dimana untuk menghasilkan output dengan kualitas yang sama, kita menggunakan input dengan jumlah yang sedikit

2. Mengelola pertumbuhan

Meningkatkan produktivitas melalui program pertumbuhan akan efektif apabila permintaan pasar meningkat. Sehingga output yang diproduksi perlu ditambah

3. Bekerja lebih tangkas

Strategi ini dilakukan apabila permintaan pasar meningkat sehingga output perlu ditingkatkan namun penigkatan output dicapai melalui peningkatan penggunaan input dengan kualitas yang tetap karena tenaga kerja telah bekerja lebih tangkas.

4. Bekerja lebih efektif

Peningkatan produktivitas dicapai melalui peningkatan output sesuai dengan peningkatan permintaan pasar dan penurunan penggunaan input.

5. Mengurangi aktifitas

Mengurangi produksi, menghilangkan atau menjual asset yang tidak produtif.

\section{Indikator produktivitas}

- Efisiensi, Efektivitas,Kerjasama ,Kualitas dan kemampuan karyawan, Kesempatan dan peranan prestasi

\section{Pengaruh Keselamatan dan Kesehatan Kerja Terhadap Produktivitas Kerja}

Keselamatan dan kesehatan kerja dan pencegahan adalah hal yang sangat penting diperhatikan oleh pemimpin. Keselamatan kerja berhubungan erat dengan produktivitas,keselamatan kerja akan membawa ketenangan dan keamanan kerja sehingga sangat membantu hubungan antara karyawan dengan pemimpin yang merupakan landasan kuat terciptanya kelangsungan produksi. Peningkatan produktivitas tenaga kerja merupakan pembaharuan pandangan hidup cultural dengan sikap mental yang memulihkan kerja serta perluasan upaya meningkatkan mutu kehidupan masyarakat.

\section{Pengaruh Turn Over Intention Dengan Produktivitas Tenaga Kerja}

Keluarnya seorang karyawan dari perusahaan ini akan mengganggu produktivitas perusahaan apalagi yang keluar tersebut karyawan yang sudah berpengalaman dan memiliki produktivitas kerja yang tinggi. Untuk itu manajemen perusahaan tidak hanya memperhatikan keselamatan dan kesehatan kerja saja tapi juga memperhatikan aktivitas karyawan dengan baik agar tidak terjadi turnover intention. Jadi dalam hal ini turnover intention sangat berpengaruh terhadap peningkatan produktivitas kerja pada PT, Persada Mandiri ini. Hal ini sesuai dengan pendapat Aprilianasari (2017) menemukan bahwa turnover intention memiliki pengaruh yang signifikan terhadap produktivitas kerja karyawan di PT Matahari Department Store Tbk Cabang Kediri. Begitu juga Penelitian yang dilakukan oleh Rompis \& Sendow (2019) terhadap perusahaan CV Segarindo Utama menemukan bahwa secara parsial turnover intention dan keterlibatan kerja berpengaruh secara signifikan terhadap produktivitas kerja.

Berdasarkan landasan teori yang dibahas diatas dengan perumusan masalah penelitian, maka dekemukakan kerangka konseptula penelitian sebagai berikut :

\section{Kerangka Koseptual Penelitian}




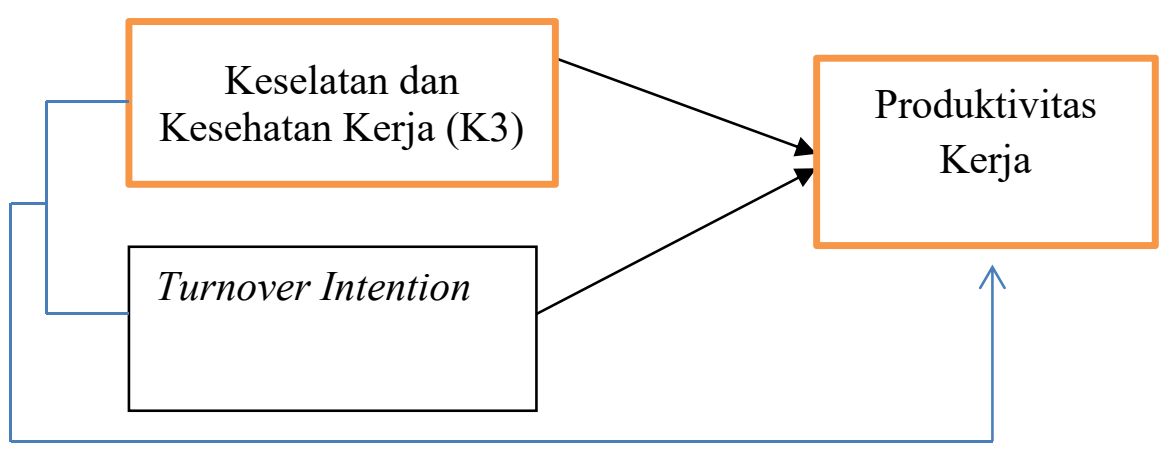

\section{Hipotesis}

\section{Gambar Kerangka Konseptual Penelitian}

Sesuai dengan perumusan maslah yang dihadapi,maka dapat di tarik hipotesisnya sebagai berikut:

1. Diduga keselamatan kerja berpengaruh terhadap produktivitas karyawan bagian lapangan pada PT Persada Mandiri.

2. Diduga Turnover Intention berpengaruh signifikan terhadap produktivitas karyawan PT. Mandiri Persada.

3. Diduga Keselamatan dan kesehatan kerja (K3) dan Turnover Intention berpengaruh signifikan terhadap produktivitas secara simultan.

\section{METODE PENELITIAN}

Penelitian ini di lakukan di PT. Persada Mandiri. Yang beralamat di komplek pulomas nomor 7 andalas padang. Sedangkan yang menjadi objek penelitian adalah karyawan bagian lapangan pada PT. Persada Mandiri.

\section{Populasi dan Sampel}

Populasi dan sampel dalam penelitian ini adalah karyawan PT. Persada Mandiri yang bekerja di bagian lapangan atau para pencatata KWH dari rumah ke rumah yaitu sebanyak 47 orang. Berhubung populasinya sedikit maka seluruh populasi langsung dijadikan sampel yaitu sebanyak 47 orang dengan teknik pengambilan sampel yaitu teknik total sampling atau sampel jenuh.

\section{Metode Pengumpulan Data}

Untuk mengumpulkan data yang diperlu dilakukan dengan cara: Penelitian Lapangan (field research) yaitu dengan menggunakan penelitian langsung kepada perusahaan yang bersangkutan dan kepada responden yang menjadi objek penelitian,jenis dan fakta yang di peroleh dari lapangan.Tinjauan pustaka (library research) yaitu dengan mencari bahan-bahan dan teori yang dapat digunakan sebagai dasar dalam pembahasan masalah. Bahan-bahan tersebut dari buku perpustakaan. Literatur-literatur serta tulisan-tulisan yang ada hubungannya dalam permasalahan yang di bahas.

\section{Sumber Data}

Dalam penelitian ini jenis data yang digunakan adalah: Data Primer yaitu data yang diperoleh dari responden berupa jawaban terhadap pertanyaan dalam kuisioner,berupa data langsung responden terhadap program keselamatan kerja perusahaan ddan produktivitas karyawan. Data Sekunder yaitu data yang diperoleh melalui studi liberator. 


\section{Variabel dan Pengukuran Variabel}

Variabel dalam penelitian ini adalah:

1. Variabel indenpenden adalah program keselamatan kesehatan kerja (X1)

2. Variabel dependen berikutnya adalah turnover intention (X2)

3. Variabel dependen adalah Produktivitas kerja (Y)

\section{Uji Instrumen}

Uji Instrumen dalam penelitian ini menggunakan uji validitas dan uji reliabilitas. Dimana Uji validitas dilakukan dengan membandingkan antara $r$ hitung dengan $r$ tabel, pengujian validitas tiap butir digunakan analisis item, yaitu mengkorelasikan skor tiap butir dengan skor total yang merupakan jumlah skor tiap butir (correccted item total correlation. Suatu pertanyaan dinyatakan valid apabila nilai , Butir-butir instrumen koefisien korelasi ( $\mathrm{r}$ hitung) $>\mathrm{r}$ tabel/ $\mathrm{r}$ kritis $(0,30)$ (sugiyono dan wibowo : 2004). Sedangkan Uji Reliabilitas

dilakukan berkaitan dengan tingkat ketepatan, keakuratan, kestabilan, dan konsistensi. Dalam penentuan tingkat reliabilitas suatu instrumen penelitian dapat diterima bila dalam kisaran $\mathrm{r}$ alpha $>0.60 \mathrm{~s} / \mathrm{d} 0.80$ dianggap baik/ reliabel serta dalam kisaran $>0.80 \mathrm{~s} / \mathrm{d} 1.00$ dianggap sangat baik/ sangat reliabel (Santoso, 2001 : 227).

Dalam hal uji validitas dan reliabilitas terhadap data dilakukan dengan menggunakan software SPSS versi 15 for windows.

\section{Uji Asumsi Klasik}

Dalam penelitian ini uji asumsi klasik yang digunakan adalah Uji Normalitas Menurut Santoso (2000 : 212 ) Uji normalitas bertujuan untuk menguji apakah data memnuhi asumsi normalitas atau tidak baik variabel dependen maupun variabel independen mempunyai distribusi normal. Selain itu juga menggunakan Uji Multikolenearitas bertujuan untuk mengetahui apakah ditemukan korelasi atau hubungan yang kuat antara variabel independen. Jika terjadi korelasi, maka dinamakan terdapat problem multikolenearitas.Untuk mendapatkan model regresi yang baik, seharusnya tidak terjadi korelasi antara variabel independen tersebut (Santoso, 2001 : 232).Selain itu kita juga melihat nilai VIF (Variance Inflation Faktor ) dengan nilai VIF sekitar angka 1 dan tolerance mendekati angka 1, sehingga dapat dikatakan bahwa model bebas dari masalah multikolenieritas (Idris,2004:61 )

\section{Metode Analisa Data} kuantitatif.

Metode analisa data yang digunakan berupa analisa kualititaf dan metode analisa

1. Metode analisa kualitatif

Membahas data yang telah diperoleh dari jawaban responden.

2. Metode analisa kuantitatif

Mengolah data yang didapat berupa angka yang diolah dalam statistic.

Dalam analisis ini akan dilakukan pengujian dengan menggunakan :

a. Data yang masuk akan dianalisis dan diuji dengan menggunakan metode analisis regresi linear berganda.

Adapun persamaan analisa regrisi linear berganda dalam penelitian ini dirumuskan diabawh ini, dimana dapat menggunakan model Hasan (2006) sebagai berikut: 


$$
\begin{aligned}
& \mathrm{Y}=\mathrm{a}+\mathrm{b} 1 . \mathrm{X} 1+\mathrm{b} 2 . \mathrm{X} 2+\mathrm{e} \\
& \begin{aligned}
\text { Dimana } & \\
\mathrm{Y} & =\text { Produktivitas Kerja } \\
\mathrm{a} & =\text { Konstanta } \\
\mathrm{b} & =\text { koefisien } \mathrm{X} \\
\mathrm{X} 1 & =\text { Keselamatan dan kesehatan kerja } \\
\mathrm{X} 2 & =\text { Turnover Intention }
\end{aligned}
\end{aligned}
$$

Selanjutnya untuk mengetahui apakah hasil yang diperoleh tersebut signifikan, dapat dilihat dari signifikansi dengan derajat kesalahannya 5\% artinya jika signifikansi dan dapat digeneralisasi dan bararti hipotesis diterima.

b. Analisa Korelasi

Analisa ini digunakan untuk mengetahui keeratan hubungan antara pengaruh keselamatan kerja terhadap produktivitas karyawandan turnover intention bagian lapangan yang bias ditentukan dengan klasifkasi korelasi yang digunakan sebagai berikut:

1. Bila koefisien korelasi antara $0,70-1,00$ positif atau negatif berarti terjadi hubungan yang kuat antara variabel $\mathrm{X}$ dan variabel $\mathrm{Y}$.

2. Bila koefisien korelasi lebih besar 0,40 tetapi lebih kecil dari 0,70 maka terdapat hubungan yang besar.

3. Bila koefisien korelasi lebih besar dari 0,20 tetapi lebih kecil dari 0,40 maka terdapat hubungan yang lemah.

c. Koefisien Determinasi

Koefisien determinasi $\left(\mathrm{R}^{2}\right)$ digunakan untuk mengukur seberapa besar variasi variabel variasi variabel dependen mampu dijelaskan oleh variabel independen.

d. $\mathrm{Uji}-\mathrm{T}$

Untuk mengetahui adanya hubungan signifikan antara pengaruh keselamatan dan kesehatan kerja terhadap produktivitas kerja dan turnover intention terhadap produktivitas kerja karyawan bagian lapangan ,maka dibandingkan besarnya nilai thitung dengan t-tabel pada $\alpha=0,05$.

Jika $\mathrm{t}$ hitung $>\mathrm{t}$ tabel maka $\mathrm{H} 0$ ditolak, $\mathrm{H} 1$ diterima artinya terdapat pengaruh signifikan antara variable independent terhadap variable dependen.

Jika thitung $<\mathrm{t}$ tabel maka $\mathrm{H} 0$ diterima, $\mathrm{H} 1$ ditolak artinya tidak terdapat pengaruh signifikan antara variable independen terhadap variable dependen.

e. $\mathrm{Uji}-\mathrm{F}$

Untuk mengetahui adanya pengaruh keselamatan dan kesehatan kerja dan turnover intention terhadap produktivitas kerja karyawan bagian lapangan secara simultan ,maka dibandingkan besarnya nilai f-hitung dengan f-tabel pada $\alpha=0,05$.

Jika $\mathrm{f}$ hitung $>\mathrm{f}$ tabel maka $\mathrm{H} 0$ ditolak, $\mathrm{H} 1$ diterima artinya terdapat pengaruh signifikan antara variable independent terhadap variable dependen secara simultan. Jika $\mathrm{f}$ hitung $<\mathrm{f}$ tabel maka $\mathrm{H} 0$ diterima, $\mathrm{H} 1$ ditolak artinya tidak terdapat pengaruh signifikan antara variable independen terhadap variable dependen secara simultan.

\section{HASIL DAN PEMBAHASAN}

Uji validitas digunakan pada tiap butir soal dengan analisis coreleted item, yaitu mengkorelasikan atau menghubungkan skor masing - masing butir dibandingkan dengan skor total yangmerupakan jumlah skor tiap butir (Sugiyono, 2013). Kuesioner dikatakan valid apabila $r$ - hitung $>$ r-tabel. Pada penelitian ini, r-tabel $>0,30$ dengan taraf 
signifikansi 5\%. Dalam penelitian ini semua pernyataan dinyatakan valid karena memiliki $r$ hitung $>r$ tabel.

Uji reliabilitas mengukur suatu indeks apakah dapat dipercaya atau dapat diandalkan. Mengetahui tingkat reliabilitas dapat dilakukan pengujian pada masing-masing data dari variabel terkait. Variabel dapat dikatakan reliabel jika variabel tersebut memberikan nilai cronbach alpha $>0,7$ (Ghozali, 2011). Hasil penelitian menunjukkan cronbach's alpha lebih besar dari 0,7 sehingga penelitian dikatakan reliable.

Uji normalitas menunjukkan adanya sebaran data yang seimbang sebagian besar data berada pada nilai di tengah. Pada prinsipnya normalitas dapat dideteksi dengan melihat penyebaran data (titik). Titik - titik tersebut mengikuti garis sumbu diagonal dari grafik atau dapat dilihat dari histogram dari residualnya (Ghozali, 2011). Pada penelitian ini terlihat titik titik menyebar membentuk diagonal,sehingga variabe -variabel dikatakan normal. Pada uji kolmogoro - smirnov dihasilkan siginifikansi sebesar 0,374 atau lebih besar dari 0,05.

Uji multikolinieritas adalah pengujian untuk mengetahui ada tidaknya kolerasi yang signifikan antara variabel-variabel independen dalam model regresi linier berganda. Untuk mendeteksi ada tidaknya multikolinieritas dalam model regresi dapat digunakan VIF dan lawannya tolerance. Nilai cutoff yang biasa dipakai untuk menunjukkan adanya Multikolinieritas adalah nilai tolerance $\geq 0,10$ atau sama dengan VIF $\leq 10$ (Ghozali, 2011).

Dari output coefficients di bawah ini, pada kolom VIF nilainya 3.633 Karena nilai VIF kurang dari 10 maka dapat disimpulkan bahwa pada model regresi tidak ditemukan adanya masalah multikolinieritas. Uji heteroskedastisitas menguji tentang penyimpangan yaitu adanya ketidaksamaan varian dan residual untuk semua pengamatan pada model regresi dalam hal ini regresi berganda. Model regresi yang baik adalah yang homoskedastisitas atau tidak terjadi heteroskedastisitas (Ghozali, 2011).

heteroskedastisitas. Persamaan regresi hasil dari penelitian ini dapat dirumuskan sebagaiberikut: $\mathrm{Y}=12,321+0,715 \mathrm{X}_{1}+0,649 \mathrm{X}_{2}$

Pada dasarnya uji-t menunjukkan seberapa besar pengaruh satu variabel penjelas secara parsial dalam menerangkan variasi variabel penjelas.

Berdasarkan pengololahan data didapat hasil Keselamatan dan kesehatan kerja $\left(\mathrm{X}_{1}\right)$ memiliki nilai sig. 0,000<0,05 ( $\alpha$ sig) dan t-hit 11,831 > t-tabel 5,991 dapat diartikan bahwa adanya pengaruh yang signifikan antara variabel bebas Keselamatan dan Kesehatan kerja $\left(\mathrm{X}_{1}\right)$ terhadap variabel terikat produktivitas kerja $(\mathrm{Y})$. Turnover Intention $\left(\mathrm{X}_{2}\right)$ memiliki nilai sig. 0,021<0,05( $\alpha$ sig) dan t-hit 9,940 > t-tabel 5,991 dapat diartikan bahwa adanya pengaruh yang signifikan antara variabel bebas Turnover Intention $\left(\mathrm{X}_{2}\right)$ terhadap variabel terikat produktivitas kerja (Y). Jadi disini apabila keselamatan dan kesehatan kerja ditingkatkan sebesar satu-satua maka, akan dapat meningkatkan produktivitas kerja pada PT.Persada Mandiri sebagai perpanjangan tangan PLN (persero) cabang Padang. Begitu juga dengan Turnover Intention jika turnover intention naik sebesar satu-satuan akan dapat meningkatkan produktivitas kerja pada PT, Persada Mandiri. Pada dasarnya uji f menunjukkan apakah semua variabel bebas yang dimasukkan dalam model mempunyai pengaruh secara bersama-sama terhadap variabel terikat (Kuncoro, 2010).

Pada uji $\mathrm{F}$ ini, didapat nilai $\mathrm{F}_{\text {-hit }}>$ dari $\mathrm{F}_{\text {-tabel }}$ dimana nilainya 577,162 $>2,920$, sehingga dapat disimpulkan bahwa secara simultan variabel bebas yaitu keselamatan dan kesehatan kerja $\left(\mathrm{X}_{1}\right)$ dan Turnover Intention $\left(\mathrm{X}_{2}\right)$ memiliki pengaruh secara signifikan terhadap variabel terikat yaitu produktivitas kerja $(\mathrm{Y})$.

Koefisien determinasi $\left(\mathrm{R}^{2}\right)$ pada intinya mengukur seberapa jauh kemampuan model 
dalam menerangkan variasi variabel terikat (Kuncoro, 2010). Pada hasil koefisien determinasi $\left(\mathrm{R}^{2}\right)$ dihasilkan nilai 0,89 atau $89,0 \%$ yang berarti bahwa pengaruh variabel bebas keselamatan dan kesehatan kerja $\mathrm{X}_{1}$ dan Turn Intention atau $\mathrm{X}_{2}$ terhadap variabel terikat Produktivitas kerj atau Y memiliki nilai sebesar 89,0\%, sedangkan sisanya $11,0 \%$ variabel yang tidak diteliti dalam penelitian ini. Ini berarti bahwa jika keselamatan dan kesehatan kerja dan Turnover Intention ditingkatkan maka akan dapat meningkatkan produktivitas kerja pada PT, Persada Mandiri,

Berdasarkan hasil analisis data yang telah dilakukan di atas, hasil penelitian menunjukkan bahwa ada pengaruh yang signifikan antara keselamatan dan kesehatan kerja $\left(\mathrm{X}_{1}\right)$ dan Turnover Intention $\mathrm{X}_{2}$ terhadap produktivitas kerja karyawan $(\mathrm{Y})$.

Berdasarkan hasil pengujian analisis data yang telah dilakukan, didapatkan regresi linierberganda yaitu $\mathrm{Y}=12,321+0,715 \mathrm{X}_{1}+0,649 \mathrm{X}_{2}$, Kemudian dari persamaan tersebut dapat diketahui bahwa perubahan yang terjadi pada variabel terikat searah dengan perubahan yang terjadi pada variabel bebas $X_{1}$ dan $X_{2}$ yang memiliki koefisien positif.

\section{PEMBAHASAN}

\section{Pengaruh Keselamatan dan Kesehatan Kerja (K3) terhadap Produktivitas Kerja Pada PT. Persada Mandiri Padang}

Hasil penelitian ini menunjukkan bahwa terdapat pengaruh secara positif dan signifikan antara kesehatan dan keselamatan kerja terhadap produktivitas kerja karyawan PT Persada Mandiri Padang. Hal ini ditunjukkan dari hasil T-hitung $>\mathrm{T}$-tabel yaitu $(11,831>5,991)$ dengan nilai signifikansi $0,000<0,05$ yang artinya Ho ditolak dan Ha diterima. Hal ini menunjukkan bahwa keselamatan dan kesehatan kerja (K3) bila ditngkatkan sebesar satu-satuan maka dapat pula meningkatkan produksivitas kerja sebesar satu-satuan. Seorang karyawan akan semangat bekerja jika dia memiliki rasa aman dalam bekerja baik dari kecelakaan kerja maupun dari omongan orang yang menunggak dalam pembayaran listrik. Begitu juga dari segi kesehatan jika karyawan tidak sehat tentu mereka tidak bisa bekerja, tapi kalau mereka sehat tentu mereka semangat dalam bekerja. Oleh sebab itu pimpinan dan menejer perusahaan selalu mengontrol karyawannya dalam bekerja apalagi pekerjaan mencatat KWH ini dilakukan menggunakan kendaraan bermotor dari rumah ke rumah dimana pekerjaan ini sarat dengan kecelakaan dijalan. Begitu pula dengan konsumen yang sering menunggak pembayaran listrik bila para pencatat $\mathrm{KWH}$ meteran datang ,maka konsumen kadang-kadang cemas dan kadang-kadang dihadapi dengan emosi. Nah ini yang dihadapi oleh karyawan pencatat KWH. Untuk itu sekarang PLN (persero) membuat sistim pra bayar dengan token listrik artinya tergantung dengan pemakaian, jika pemakaian besar maka cepatlah habisnya pulsa yang diisi oleh konsumen.Jadi dengan meningkatnya keselamatan dan kesehatan kerja dari para karyawan maka akan dapat meningkatkan produktivitas kerja pada PT. Persada Mandiri Padang.

2. Pengaruh Turnover Intention Terhadap Produktivitas Kerja Pada PT. Persada Mandiri Padang

Selanjutnya begitu juga dengan turnover intention memiliki pengaruh yang signifikan terhadap produktivitas kerja. Hal ini ditunjukkan dari hasil $\mathrm{T}$-hitung $>\mathrm{T}$-tabel yaitu $(9.940>5,991)$ dengan nilai signifikansi $0,021<0,05$ yang artinya Ho ditolak dan Ha diterims. Dengan keadaan pekerjaan yang sekarang diperlukan jam perpindahan kerja karyawan (shift), kondisi karyawan (burnout), dan penyesuaian target atau beban kerja. Pada penelitian ini dapat disimpulkan apabila turnover 
intention naik, maka akan berpengaruh terhadap produktivitas kerja karyawan. Penelitian ini diperkuat dengan penelitian sebelumnya yang dilakukan oleh Aprilianasari (2017), yang menyatakan bahwa turnover intention berpengaruh positif dan signifikan terhadap produktivitas kerja. Apalagi pekerjaan mencatat KWH ini penuh dengan tantangan dilapangan kadang-kadang KWH meterannya banyak yang dirobah sehingga kalau ditegur konsumen marah ini tantangan bagi pencatat KWH dan kadang-kadang ingin keluar saja bekerja tapi apabila manajemen bagus dalam pengelolaan karyawan sehingga karyawan tetap bertahan dalam bekerja. Hal ini menunjukkan bahwa turnover Intention memiliki hubungan yang positif dengan produktivitas kerja pada PT, Persada Mandiri Padang.

\section{E. KESIMPULAN}

Berdasarkan hasil Uji Hipotesis dan pembahsan, maka dapat diperoleh kesimpulan beberapa hal. Pertama keselamatan dan kesehatan kerja berpengaruh positif dan signifikan terhadap produktivitas kerja di PT Persada Mandiri Padang. Apabila terjadi peningkatan keselamatan dan kesehatan kerja, maka akan berpengaruh positif terhadap produktivitas kerja. Kedua, Turnover Intention secara signifikan berpengaruh positif terhadap produktivitas kerja di PT Persada Mandiri Padang. Apabila terjadi peningkatan atau pergantian karyawan dengan karyawan yang sudah berpengalaman , maka akan terjadi peningkatan terhadap produktivitas kerja. Ketiga, secara bersamaan variabel keselamatan dan kesehatan kerja (K3) dan turnover intention di PT Persada Mandiri Padang berpengaruh secara signifikan terhadap produktivitas kerja dengan nilai $\mathrm{F}_{\text {-hitung }}>\mathrm{F}_{\text {-tabel. }}$

\section{Saran} berikut :

Berdasarkan hasil penelitian ini maka disarankan kepada perusahaan hal-hal sebagai

1. Meningkatkan keselamatan dan kesehatan kerja karyawan.

2. Meningkatkan keamanan dan kenyamanan karyawan dalam bekerja.

3. Menghindari adanya turnover intention bagi karyawan.

\section{F. DAFTAR PUSTAKA}

Aprilianasari, R. (2017). Pengaruh Turn Over Dispilin Kerja dan Prestasi Kerja Terhadap Produktivitas Karyawan Bagian Kasir di PT. Matahari Department Store Kediri. Simki- Economic, 1-12. Retrieved from http://simki.unpkediri.ac.id/detail/12.1.02.02.0532

Asmara, A.P. (2017). Pengaruh Turnover Intention Terhadap Kinerja Karyawan Di RumahSakit Bedah Surabaya. Jurnal Administrasi Kesehatan Indonesia, 5(2), 123-129.

Febrianto, A., Minarsih, A. M. M. M., \& Warso, M. M. (2016). Pengaruh Insentif, Komunikasi dan Lingkungan Kerja Terhadap Kepuasan Kerja dan Implikasinya

Terhadap Produktivitas Kerja Di CV. Duta Karya Semarang. Journal of Management 2(2). 
Fu'ad, E. N., \& Gumilar, A. G. (2018). Studi empiris pengaruh kepuasan kerja, turnover intention, produktivitas, dan keunggulan bersaing. Jurnal Ekonomi Dan Bisnis, 21(2),175-202. https://doi.org/10.24914/jeb.v21i2.1821

Ghozali, I. (2011). Aplikasi Analisi Multivariate Dengan Program SPSS 19. Edisi KelimaSemarang : Bandan Penerbitan Universitas Diponegoro.

Hendri, E., \& Rismansyah. (2016). Pengaruh Kepuasan Kerja Dan Semangat Kerja Terhadap Produktivitas Kerja Karyawan Pada Pt. Selapan Jaya Ogan Komering Ilir. Jurnal Wahana Ekonomika, 13(1), 1-15.

Hoboubi N, Choobineh A, Kamari G.F, Keshavarzi S, Akbar H.A. (2017). The Impact of Job Stress and Job Satisfaction on Workforce Productivity in an Iranian Petrochemical Industry. Saf Health Work, 8(1), 67-71.

Huselid, M. A. (2018). The Impact Of Human Resource Management Practices On Turnover, Productivity, And Corporate Financial Performance. Academy of Management Journal, 38(3), 635-872 https://doi.org/10.5465/256741

Kuncoro, M. (2010). Metode Kuantitatif: Teori dan Aplikasi Untuk Bisnis dan Ekonomi. Yogyakarta : AMP YKPN

Hasibuan, M.A.P. (2012). Manajemen Sumber Daya Manusia. Jakarta: PT.Bumi Aksara.https://doi.org/10.1016/j.chemosphere.2018.05.062

Muayyad, D. M., \& Gawi, A. I. O. (2016). Pengaruh Kepuasan Kerja Terhadap Produktivitas Kerja Pegawai Bank Syariah X Kantor Wilayah II. Jurnal Manajemen Dan Pemasaran Jasa, 9(1), 75-98. https://doi.org/http://dx.doi.org/10.25105/jmpj.v9i1.1396

Rompis, J., \& Sendow, G. (2019). Pengaruh Insentif, TurnOver dan Keterlibatan Kerja Terhadap Produktivitas Kerja Karyawan CV. Segarindo Utama Minahasa. EMBA : Jurnal Riset Ekonomi, Manajemen, Bisnis Dan Akuntansi, 7(1), 1081 1090. Retrieved from https://ejournal.unsrat.ac.id/index.php/emba/article/view/23239 